\title{
METABOLIC SYNDROME INSTEAD OF AFLATOXIN-RELATED TP53 R249S MUTATION AS A HEPATOCELLULAR CARCINOMA RISK FACTOR
}

\author{
Estefanie N. Valdés-Peregrina, Beatriz E. Sánchez-Hernández, and Armando Gamboa-Domínguez* \\ Department of Pathology, Instituto Nacional de Ciencias Médicas y Nutrición Salvador Zubirán, Mexico City, Mexico
}

\begin{abstract}
Background: Hepatocarcinogenesis has a variety of risk factors. In Mexico City, autopsies found 14\% of hepatocellular carcinomas (HCCs) without cirrhosis. Objective: The objective of the study was to explore if HCCS carry the TP53 R249S mutation that has linked them to aflatoxin exposure and describe the associated risk factors. Methods: A retrospective review of consecutive cases of HCC was performed. Exposure to hepatotropic viruses, alcoholism, metabolic diseases, diabetes mellitus, and hypertension, as well as episodes of ascites, portal hypertension, and body mass index were retrieved. Slides were re-reviewed, macrodissected and DNA was extracted. TP53 exon 7 was amplified, purified, and used as a template for sequencing. Results: In 14 years, 74 HCCs were identified in 1863 (4\%) consecutive liver biopsies. No data were available in five excluded patients; the rest was submitted to exon 7 screening. Patients had a median age of 62 years, and 46 (67\%) were male. Stage 4 fibrosis was observed in 46 patients (67\%) and their associated risk factors were hepatitis $C$ virus (39\%, $18 / 46)$, alcoholism $(20 \%, 9 / 46)$, hepatitis B virus (2\%, 1/46), and 18 were cryptogenic. Fibrosis stage 3 or lower was observed in 23 (33\%) patients without demonstrated liver disease; 8/23 had diabetes and 6/23, systemic hypertension. Steatohepatitic variants of HCC were observed in 4 and in 5, the remnant liver had steatohepatitis. A 238-bp fragment was obtained in each tumor without the expected TP53 R249S mutation. Conclusions: There was no evidence of aflatoxin exposure in HCCs, with and without the known "classical" risk factors. One-third of non-cirrhotic HCCs had steatohepatitis or conditions associated to metabolic syndrome. (REV INVEST CLIN. 2020;72(5):316-22)
\end{abstract}

Key words: Hepatocellular carcinoma. Metabolic syndrome. Aflatoxin. Steatohepatitis. Diabetes mellitus. Dyslipidemia.

\section{INTRODUCTION}

Hepatocellular carcinoma (HCC) is the second most common cause of cancer death worldwide; its risk factors are diverse and evolving, with regional trends in many societies ${ }^{1}$. In Mexico, mortality due to viral hepatitis, liver tumors, and cirrhosis is increasing in northern and central states ${ }^{2}$, and HCC was the most common primary liver cancer in 2006 with a mortality rate of $4.7 / 100,000^{3}$. During the early 90s, in Mexico City, a two-fold increase in the incidence of HCC was observed among 12,556 autopsies performed over a
*Corresponding author:

Armando Gamboa-Domínguez

E-mail: armando.gamboad@incmnsz.mx, agamboad@gmail.com
Received for publication: 5-12-2019

Approved for publication: 02-04-2020

DOI: $10.24875 / R I C .20003328$

0034-8376 / (C) 2020 Revista de Investigación Clínica. Published by Permanyer. This is an open access article under the CC BY-NC-ND license (http://creativecommons.org/licenses/by-nc-nd/4.0/). 
25 -year period 4 . Incidence of cirrhosis was $4 \%$ in that sample of middle-income patients, and $14 \%$ of HCCs were found in non-cirrhotic livers. In other studies, non-cirrhotic HCC has a frequency that ranges from $1.7 \%$ to $19 \%$, in patients without clear associated risk factors $^{5-7}$. A local study of 1486 cirrhotic patients identified alcoholism (39.5\%), hepatitis C virus (HCV) infection (36.6\%), primary biliary cholangitis (5.7\%), and hepatitis B virus (HBV) infection ( $5 \%$ ) as frequent etiologies of end-stage liver disease ${ }^{8}$, but 154 (10.4\%) of them were cryptogenic cirrhosis ${ }^{8}$.

Tortillas (corn flour flat bread) are a staple food consumed in a daily basis in Mexico, and a recent Mexican study ${ }^{9}$ showed that $13 \%$ contained levels of aflatoxin that exceed the allowed national quantification limits $(>12 \mu \mathrm{g} / \mathrm{kg})$. Aflatoxins are the carcinogenic and mutagenic mycotoxins of Aspergillus parasiticus and Aspergillus flavus. Food contamination mainly with aflatoxins type B1 (AFB1) has been associated with HCC development in Southeast Asia and subSaharan Africa $^{10}$, regions with a high prevalence of HBV exposure. Both are risk factors for hepatocarcinogenesis, but AFB1 induces DNA adducts and consequently promotes oxidative damage and G-T transversion in codon 249 of the TP53 tumor suppressor gene $T P 53^{10}$. The R249S mutation has been found in more than $60 \%$ of HCC patients exposed to excess dietary $A F B 1^{11-13}$. In fact, two independent studies using polymerase chain reaction (PCR) and mass spectrometry analysis in tumoral and blood samples from regions with a high prevalence of HCC and AFB1 exposure had proposed TP53 R249S mutation as a pre-diagnosis serum biomarker of HCC since $88.5 \%$ concordance between tumoral tissue and matched plasma was found ${ }^{13,14}$. In Guanxi, China, where $>50 \%$ of HCC had the exposure, a molecular screening of all TP53 exons showed R249S as the most frequent missense mutation in patients with and without HBV infection ${ }^{15}$. An earlier study analyzing $21 \mathrm{HCC}$ patients from Northeastern Mexico, found $76 \%$ with AFB1 serum adducts, and of 16 amplified cases, 3 (19\%) had the TP53 R249S mutation ${ }^{16}$. After this single report, without a confirmatory local study, our country was considered as an intermediate risk zone for this carcinogenic pathway in the liver ${ }^{16,17}$.

In Latin America, the genotypes $\mathrm{H}$ and $\mathrm{F}$ of hepatitis $\mathrm{B}$ appear to have a more benign course of disease ${ }^{18}$, with few HCC cases associated with this infection ${ }^{19,20}$.
Our objective was to study whether HCC in Mexican Mestizo patients carry the TP53 R249S mutation linked to aflatoxin exposure and describe its associated risk factors in patients with and without cirrhosis.

\section{METHODS}

Data from HCC-treated patients with available liver biopsies, follow-up, and clinical information were identified in surgical pathology files from an academic medical center. Exposure to hepatotropic viruses, alcoholism, metabolic diseases, diabetes mellitus, hypertension, episodes of ascites, portal hypertension, and the body mass index were retrieved from clinical charts. Slides were re-reviewed to identify HCC and remnant hepatic tissue was reassessed for fibrosis and steatohepatitis. Macrodissection of neoplastic cells was performed; DNA was purified from paraffinembedded tissue samples containing at least $70 \%$ of tumor cells using the QIAamp DNA FFPE Tissue kit (Qiagen, Hilden, Germany), following manufacturer's recommendations. In all cases, the total amount of DNA obtained was greater than $300 \mathrm{ng}$. A product of $238 \mathrm{bp}$ that included the exon 7 of TP53 was amplified by PCR. The reaction was performed using $25 \mathrm{ng}$ of tissue DNA, $20 \mu \mathrm{l}$ of $2 \times$ HotStarTaq Plus Master Mix Kit (QIAGEN), and $0.25 \mu \mathrm{M}$ forward 5'-CTTGCCACAGGTCTCCCCAA-3' and reverse 5'-AGGGGTCAGAGGCAAGCAGA-3' primers in a final volume of $40 \mu$ l. The PCR reaction consisted of 40 cycles in the following conditions: $98^{\circ} \mathrm{C}$ for $30 \mathrm{~s}$, $60.8^{\circ} \mathrm{C}$ for $40 \mathrm{~s}$, and $68^{\circ} \mathrm{C}$ for $40 \mathrm{~s}$. PCR products were purified using QIAquick Gel Extraction kit (Qiagen, Hilden, Germany) and used as template for direct sequencing with the $3130 \times$ I Genetic Analyzer (Applied Biosystems, Foster City, CA). The sequence NM_000546 (GenBank) was used as a reference. The study was performed in accordance with the Code of Ethics of the World Medical Association (Declaration of Helsinki).

\section{RESULTS}

From the years 2002 to 2015,74 HCC patients were identified among 1863 consecutive liver biopsies (4\%). No clinical data were available in five patients; 
Table 1. Associated conditions and risk factors in HCC. None of the tumors exhibited the TP53 R249S mutation of AFB1 exposure $(n=69)$. Data extracted from clinical records and reevaluation of tumor slides of patients with and without cirrhosis

\begin{tabular}{lcc}
\hline Risk factor for HCC & $\begin{array}{c}\text { Cirrhotic HCC } \\
(\mathrm{n}=46)\end{array}$ & $\begin{array}{c}\text { Non-cirrhotic HCC } \\
(\mathrm{n}=23)\end{array}$ \\
\hline Hepatitis C virus & 18 & 0 \\
Alcohol & 9 & 0 \\
Hepatitis B virus & 1 & 0 \\
Type 2 diabetes* & 0 & 8 \\
Systemic hypertension & 0 & 6 \\
Steatohepatitis** & 0 & 5 \\
Steatohepatitic HCC & 0 & 4 \\
Cryptogenic cirrhosis & 18 & 0 \\
\hline
\end{tabular}

*Six patients with type 2 diabetes mellitus (T2DM) also had systemic hypertension, two with dyslipidemia, and one T2DM, hypertension, and overweight.

**One patient had steatohepatitis in remnant liver tissue and steatohepatitic variant of HCC. HCC: hepatocellular carcinoma.

therefore, they were excluded. Patients submitted to exon 7 screening had a median age of 62 years and $46(67 \%)$ were male. Stage 4 fibrosis was observed in 46 patients (67\%); the main risk factors for cirrhosis development were HCV infection (HCV, 39\%, 18/46), alcoholism (20\%, 9/46), and HBV infection (HBV $2 \%, 1 / 46)$, and in 18 (39\%), cirrhosis was recorded as cryptogenic. Stage 3 fibrosis or lower stages were observed in 23 cases (33\%) without a demonstrated chronic liver disease. Of these patients, $8 / 23$ had type 2 diabetes mellitus (T2DM) and 6/23, systemic hypertension. Six T2DM patients also had hypertension, two had dyslipidemia, and one had T2DM, hypertension, and overweight (Table 1). Remnant liver tissue was present in $11 / 23$ samples without cirrhosis; in five of these patients, steatohepatitis with interlaminar fibrosis stage 2 was observed. In addition, four patients had tumors with steatosis, abundant Mallory bodies, and satellitosis, one of them also with steatohepatitis in residual tissue. None of them presented the ground-glass cytoplasm nor surface/core antigen expression suggesting HBV infection, as was routinely ruled out by immunohistochemistry.

Tumor grading according to the Edmondson-Steiner and WHO modifications ${ }^{21}$ was well differentiated (G1-G2) 31 (45\%); moderate (G3) 23 (33\%); and poorly differentiated (G4) 12 (17\%), without differences between cirrhotic and non-cirrhotic tissue. Three (4\%) fibrolamellar HCC subtypes were observed in livers without fibrosis. A 238-base pair fragment of DNA was obtained in each tumor, and its direct sequencing did not show the AGG-AGT or AGG-AGC mutation expected in codon 249 of the exon 7 of TP53.

\section{DISCUSSION}

AFB1 synthesized by Aspergillus spp. is one of the most common carcinogens in foods such as rice, cereals, fruits, vegetables, and corn, among others ${ }^{17}$. This toxin is chemically stable and resistant to various processes such as cooking or boiling ${ }^{17}$. Corn contamination with AFB1 was documented early in the 90s in Northeastern Mexico ${ }^{9,16}$. Recent findings of tortilla contamination with this carcinogen in Mexico City suggest extensive exposure and protean clinical expressions $9,16,22$. Its most feared complication is HCC development in regions with high prevalence of HBV infection; however, none of our cases in this study carried the TP53 mutation linked to AFB1 exposure. Explanations for this finding could be the low prevalence of HBV as an additional risk factor in the analyzed patients ( $1 \mathrm{HCC} / \mathrm{HBV}$ among $69 \mathrm{HCC}$ ). Gain of oncogenic function of TP53 R249S mutation depends on the microenvironmental milieu that HBV creates, leading to post-translational modifications and neoplastic cell survival advantages, as was recently described $^{23}$. A second explanation could be that AFB1 
Table 2. TP53 R249S mutation in HCC in different countries and regions

\begin{tabular}{|c|c|c|c|c|c|c|}
\hline Region & Specimen & $\begin{array}{c}\text { TP53 R249S+ve/ } \\
\text { HCC (\%) }\end{array}$ & $\begin{array}{l}\text { Detection } \\
\text { method }\end{array}$ & $\begin{array}{l}R 249 S \text { mutation } \\
\text { and serum } \\
\text { AFB1 adducts }\end{array}$ & Year & Reference \\
\hline \multicolumn{7}{|l|}{ Africa } \\
\hline Southern Africa & Tumor & $3 / 10(33)$ & Sequencing & ND & 1991 & 31 \\
\hline Mozambique & Tumor & $8 / 15(53)$ & RFLP & ND & 1991 & 12 \\
\hline Senegal & Tumor & $10 / 15(67)$ & RFLP & ND & 1993 & 32 \\
\hline Gambia & Tumor & $11 / 18(61)$ & RFLP and sequencing & ND & 2004 & 14 \\
\hline Gambia & Tumor & $43 / 56(77)$ & RFLP & ND & 2012 & 33 \\
\hline Nigeria & Plasma & $6(7)$ & RFLP and sequencing & ND & 2008 & 34 \\
\hline Egypt & $\begin{array}{l}\text { Tumor } \\
\text { Serum }\end{array}$ & $\begin{array}{l}2 / 20(10) \\
1 / 76(1)\end{array}$ & RFLP and sequencing & $\begin{array}{l}\text { ND } \\
\text { ND }\end{array}$ & 2008 & 35 \\
\hline \multicolumn{7}{|l|}{ Asia } \\
\hline Qidong, China & $\begin{array}{l}\text { Tumor } \\
\text { Plasma }\end{array}$ & $\begin{array}{l}11 / 18(61) \\
2 / 130(2)\end{array}$ & $\begin{array}{l}\text { RFLP } \\
\text { SOMA }\end{array}$ & $\begin{array}{l}\text { ND } \\
\text { ND }\end{array}$ & 2009 & 36 \\
\hline Guangxi, China & Tumor & $18 / 50(36)$ & Sequencing & ND & 2001 & 37 \\
\hline Beijing, China & Tumor & $1 / 116(1)$ & PCR-SSCP and sequencing & ND & 2013 & 38 \\
\hline Thailand & Tumor & $6 / 25(24)$ & SOMA & ND & 2005 & 39 \\
\hline Thailand & Plasma & $29 / 84(35)$ & SOMA & ND & 2012 & 40 \\
\hline Japan & Tumor & $3 / 279(9)$ & Sequencing & $3 / 3$ & 2011 & 41 \\
\hline Japan & Tumor & $3 / 34(9)$ & PCR-SSCP and sequencing & ND & 1993 & 42 \\
\hline Japan & Tumor & $7 / 140(5)$ & PCR-SSCP and sequencing & ND & 1992 & 43 \\
\hline Japan & Tumor & $0 / 59(0)$ & $\mathrm{PCR}$ and $\mathrm{OH}$ & ND & 1993 & 44 \\
\hline Singapore & Tumor & $0 / 44(0)$ & RFLP & ND & 1995 & 45 \\
\hline India & Tumor & $2 / 21(10)$ & PCR-SSCP and sequencing & ND & 2000 & 46 \\
\hline \multicolumn{7}{|l|}{ Europe } \\
\hline Italy and France & Tumor & $0 / 7(0)$ & Sequencing & ND & 1993 & 47 \\
\hline Great Britain & Tumor & $0 / 19(0)$ & PCR-SSCP and sequencing & ND & 1992 & 48 \\
\hline Germany & Tumor & $0 / 20(0)$ & Sequencing & ND & 1995 & 49 \\
\hline Italy & Tumor & $0 / 20(0)$ & Sequencing & ND & 1995 & 50 \\
\hline Turkey & Tumor & $1 / 50(2)$ & RFLP & ND & 2010 & 51 \\
\hline \multicolumn{7}{|l|}{ America } \\
\hline Brazil & Tumor & $21 / 74(28)$ & RFLP & ND & 2009 & 52 \\
\hline United States & Tumor & $4 / 37(11)$ & RFLP & ND & 1993 & 53 \\
\hline $\begin{array}{l}\text { Hispanics in } \\
\text { South Texas }\end{array}$ & Tumor & $3 / 41(7)$ & RFLP & ND & 2018 & 54 \\
\hline Alaska & Tumor & $0 / 13(0)$ & Sequencing & ND & 1995 & 55 \\
\hline Colombia & Tumor & $4 / 38(11)$ & RFLP and sequencing & $0 / 4$ & 2011 & 56 \\
\hline Colombia & Tumor & $1 / 30(3)$ & RFLP & ND & 2019 & 57 \\
\hline México & Tumor & $3 / 16(19)$ & Sequencing & $2 / 3$ & 1996 & 16 \\
\hline Mexico & Tumor & $0 / 69(0)$ & Sequencing & ND & 2020 & Present study \\
\hline
\end{tabular}

RFLP: restriction fragment length polymorphism; PCR-SSCP: polymerase chain reaction and single-strand conformation polymorphism; $\mathrm{OH}$ : oligonucleotide hybridization; SOMA: short oligonucleotide mass analysis; ND: not determined. 
exposure became inconstant once the liver mass was present, leading to disappearance of its mutational signature through clonal and subclonal evolution of $\mathrm{HCC}^{24}$. Although a previous report states AFB1 exposure as a concern for HCC in Mexico ${ }^{16}$, our sample with only one case of HBV infection is not confirmatory; instead, it should lead to consider other players in hepatocarcinogenesis ${ }^{8}$, since hepatotropic viruses and alcoholism merely explained $40.5 \%$ of the analyzed cases $(28 / 69)$.

The frequency of non-cirrhotic HCC in our study was $33 \%$, higher than the previously observed range of $1.7-19 \%^{5-7,25}$. Adding cases of cryptogenic cirrhosis - where no known risk factor leading to cirrhosis was found - to non-cirrhotic HCC cases, the percentage of HCC without a well-documented risk factor was almost $60 \%$ in the present study. Aside of hepatotropic viruses and alcohol, new risk factors have been associated to HCC development ${ }^{26}$ and should be analyzed in future studies in Mexico, a country where HCC prevalence in postmortem studies rose from $0.35 \%$ in $1965-1969$ to $0.69 \%$ in 1985-19891,4.

Fibrolamellar hepatic carcinoma, the carcinoma subtype usually observed in non-cirrhotic liver ${ }^{27}$, was identified in three patients, four HCCs were steatohepatitic $^{28}$, and the rest were conventional HCCs with trabecular and acinar patterns, none of them with the TP53 R249S mutation. Non-tumoral liver tissue showed steatohepatitis in five patients with fibrosis Stage 3 or lower. In a country with high prevalence of obesity and diabetes as is Mexico ${ }^{29}$, our results suggest that the metabolic syndrome could be involved in patients developing HCC without cirrhosis ${ }^{30}$.

Although it is important to recognize the limitation of the present retrospective series lacking AFB1albumin adducts level measurement in serum ${ }^{16,17}$, in concordance with other studies (Table 2), our negative result reflects the wide variations of this association around the globe ${ }^{31-57}$. Without diminishing credibility to the previous studies also lacking adduct exploration in serum ${ }^{36,38-40}$, two studies done in Asia showed lower frequencies of TP53 R249S in that region ${ }^{37,41}$, and there is the pioneering study of Mexican patients done abroad in a collection of only 16 liver tumors and plasma ${ }^{16}$. In our setting, where end-stage liver disease screening is exhaustive, steatohepatitis and conditions associated to metabolic syndrome warrant the reassessment of clinical records and liver tissue beyond the well-known "classical" risk factors for hepatocarcinogenesis. The silent natural history of liver lipotoxicity is starting to be unveiled in Mexico ${ }^{58}$, and more and larger studies on chronic liver damage, with in-depth clinical and molecular analyses, are required to elucidate further our interesting findings.

In the absence of HBV infection, no evidence of aflatoxin involvement in hepatocarcinogenesis was revealed in this retrospective study. More than half of HCC lacked a known risk factor for end-stage liver disease. In addition to the traditional risk factors, steatohepatitis or conditions associated with metabolic syndrome were frequent in 69/1863 (4\%) HCC obtained from consecutive liver biopsies.

\section{REFERENCES}

1. Llovet JM, Zucman-Rossi J, Pikarsky E, Sangro B, Schwartz M, Sherman M, et al. Hepatocellular carcinoma. Nat Rev Dis Primers. 2016;2:16018.

2. Méndez-Sánchez N, García-Villegas E, Merino-Zeferino B, Ochoa-Cruz S, Villa AR, Madrigal H, et al. Liver disease in Mexico and their associated mortality trends from 2000 to 2007: a retrospective study of the nation and federal states. Ann Hepatol. 2010;9:428-38.

3. Méndez-Sánchez N, Villa AR, Vázquez-Elizondo G, PoncianoRodríguez G, Uribe M. Mortality trends for liver cancer in Mexico from 2000 to 2006. Ann Hepatol. 2008;7:226-9.

4. Cortes-Espinosa T, Mondragón-Sánchez R, Hurtado-Andrade H, Sánchez-Cisneros R. Hepatocellular carcinoma and hepatic cirrhosis in Mexico: a 25 year necropsy review. Hepatogastroenterology. 1997;44:1401-3.

5. Okuda K, Nakashima T, Kojiro M, Kondo Y, Wada K. Hepatocellular carcinoma without cirrhosis in Japanese patients. Gastroenterology. 1989;97:140-6.

6. Gianninia EG, Marencoa S, Bruzzone L, Savarino V, Farinati F, Del Poggio $\mathrm{P}$, et al. Hepatocellular carcinoma in patients without cirrhosis in Italy. Dig Liver Dis. 2013;45:164-9.

7. Martínez ON, Peña AM, Rodríguez BM, Sánchez AD, Rodríguez AC, Bottella ER, et al. Descriptive study of hepatocellular carcinoma in noncirrhotic liver. Gastroenterol Hepatol. 2011;34:322-8.

8. Méndez-Sánchez N, Aguilar-Ramírez JR, Reyes A, Dehesa M, Juárez A, Castañeda B, et al. Etiology of liver cirrhosis in Mexico. Ann Hepatol. 2004;3:30-3.

9. Castillo-Urueta P, Carvajal M, Méndez I, Meza F, Gálvez A. Survey of aflatoxins in maize tortillas from Mexico city. Food Addit Contam Part B Surveill. 2011;4:42-51.

10. Goopman D, Cain LG, Kensler TW, Harris CC. Aflatoxin exposure in human population: measurements and relationship to cancer. Crit Rev Toxicol. 1988;19:113-45.

11. Hsu IC, Metcalf RA, Sun T, Welsh JA, Wang NJ, Harris CC. Mutational hotspot in the p53 gene in human hepatocellular carcinomas. Nature. 1991;350:427-8.

12. Ozturk M. p53 mutation in hepatocellular carcinoma after aflatoxin exposure. Lancet. 1991;338:1356-9.

13. Jackson PE, Kuang SY, Wang JB, Strickland PT, Muñoz A, Kensler TW, et al. Prospective detection of codon 249 mutations in 
plasma hepatocellular carcinoma patients. Carcinogenesis. 2003;24:1657-63.

14. Szymanska K, Lesi OA, Kirk GD, Sam O, Taniere P, Scoazec JY, et al. Ser-249TP53 mutation in tumor and plasma DNA of hepatocellular carcinoma patients from a high incidence area in the Gambia, West Africa. Int J Cancer. 2004;110:374-9.

15. Qi LN, Bai T, Chen ZS, Wu FX, Chen YY, De Xiang B, et al. The p53 mutation spectrum in hepatocellular carcinoma from Guangxi, China: role of chronic hepatitis B virus infection and aflatoxin B1 exposure. Liver Int. 2015;35:999-1009.

16. Soini Y, Chia SC, Bennett WP, Groopman JD, Wang JS, DeBenedetti VM, et al. An aflatoxin-associated mutational hotspot at codon 249 in the p53 tumor suppressor gene occurs in hepatocellular carcinomas from Mexico. Carcinogenesis. 1996; 17:1007-12.

17. Pitt Jl, Wild CP, Baan RA, Gelderblom WC, Miller JD, Riley R, et al. Improving public health through mycotoxin control. Lyon: International Agency for Research on Cancer; 2012.

18. Román S, José-Abrego A, Fierro NA, Escobedo-Meléndez G, Ojeda-Granados, Martínez-López E, et al. Hepatitis B virus infection in Latin America: a genomic medicine approach. World J Gastroenterol. 2014;20:7181-96.

19. Piñero F, Costa P, Boteon YL, Duque SH, Marciano S, Anders $M$, et al. A changing etiologic scenario in liver transplantation for hepatocellular carcinoma in a multicenter cohort study from Latin America. Clin Res Hepatol Gastroenterol. 2018; 42:443-52.

20. Román S, Panduro A, Aguilar-Gutiérrez $Y$, Maldonado $M$, Vázquez-Vandyck M, Martínez-López E, et al. A low steady HBsAg seroprevalence is associated with a low incidence of HBVrelated liver cirrhosis and hepatocellular carcinoma in Mexico: a systematic review. Hepatol Int. 2009;3:343-55.

21. Martins-Filho SN, Paiva C, Soares-Azevedo R, Ferreira-Alves VA. Histological grading of hepatocellular carcinoma a systematic review of literature. Front Med (Laussane). 2017;4:193.

22. Leroy JL, Sununtnasuk C, García-Guerra A, Wang JS. Low level aflatoxin exposure associated with greater linear growth in southern Mexico: a longitudinal study. Matern Child Nutr. 2018;14:e12619.

23. Liao $P$, Zeng SX, Zhou X, Chen T, Zhou F, Cao B, et al. Mutant p53 gains its function via c-Myc activation upon CDK4 phosphorylation at serine 249 and consequent PIN1 binding. Mol Cell. 2017;68:1134-46.

24. Letouzé E, Shinde J, Renault V, Couchy G, Blanc JF, Tubacher E, et al. Mutational signatures reveal the dynamic interplay of risk factors and cellular processes during liver tumorigenesis. Nat Commun. 2017;8:1315

25. Van Meer S, van Erpecum KJ, Sprengers D, Coenraad MJ, Klümpen $\mathrm{HJ}$, Jansen $\mathrm{PL}$, et al. Hepatocellular carcinoma in cirrhotic versus noncirrhotic livers: results from a large cohort in the Netherlands. Eur J Gastroenterol Hepatol. 2016;28: 352-9.

26. Bhaskaran K, Douglas I, Forbes $\mathrm{H}$, dos-Santos-Silva I, Leon DA, Smeeth L. Body-mass index and risk of 22 specific cancers: a population-based cohort study of 5.24 million UK adults. Lancet. 2014;384:755-65

27. Arista-Nasr J, Gutiérrez-Villalobos, Nuncio J, Maldonado $H_{\text {, }}$ Bornstein-Quevedo L. Fibrolamellar hepatocellular carcinoma in Mexican patients. Pathol Oncol Res. 2002;8:133-7.

28. Salomao M, Yu WM, Brown RS Jr., Emond JC, Lefkowitch JH. Steatohepatitic hepatocellular carcinoma (SH-HCC): a distinctive histological variant of HCC in hepatitis $C$ virus-related cirrhosis with associated NAFLD/NASH. Am J Surg Pathol. 2010;34:1630-6.

29. Bello-Chavolla OY, Rojas-Martínez R, Aguilar-Salinas CA, Hernández-Avila M. Epidemiology of diabetes mellitus in Mexico. Nutr Rev. 2017;75 Suppl 1:4-12.

30. Kasmari AJ, Welch A, Liu G, Leslie D, McGarrity T, Riley T. Independent of cirrhosis, hepatocellular carcinoma risk is increased with diabetes and metabolic syndrome. Am J Med. 2017;130:745.e1-7

31. Bressac B, Kew M, Wands J, Ozturk M. Selective G to T mutations of p53 gene in hepatocellular carcinoma from Southern Africa. Nature. 1991;350:429-31.

32. Coursaget $P$, Depril N, Chabaud M, Nandi R, Mayelo V, LeCann $P$, et al. High prevalence of mutations at codon 249 of the p53 gene in hepatocellular carcinomas from Senegal. $\mathrm{Br}$ J Cancer. 1993;67:1395-7.
33. Gouas DA, Villar S, Ortiz-Cuaran S, Legros P, Ferro G, Kirk GD, et al. TP53 R249S mutation, genetic variations in HBX and risk of hepatocellular carcinoma in The Gambia. Carcinogenesis. 2012;33:1219-24.

34. Igetei R, Otegbayo JA, Ndububa DA, Lesi OA, Anumudu Cl, Hainaut $P$, et al. Detection of p53 codon 249 mutation in Nigerian patients with hepatocellular carcinoma using a novel evaluation of cell-free DNA. Ann Hepatol. 2008;7:339-44.

35. Hosny G, Farahat N, Tayel H, Hainaut P. Ser-249 TP53 and CTNNB1 mutations in circulating free DNA of Egyptian patients with hepatocellular carcinoma versus chronic liver diseases. Cancer Lett. 2008:264:201-8

36. Szymañska K, Chen JG, Cui Y, Gong YY, Turner PC, Villar S, et al. TP53 R249S mutations, exposure to aflatoxin, and occurrence of hepatocellular carcinoma in a cohort of chronic hepatitis B virus carriers from Qidong, China. Cancer Epidemiol Biomarkers Prev. 2009;18:1638-43.

37. Stern MC, Umbach DM, Yu MC, London SJ, Zhang ZQ, Taylor JA Hepatitis $B$, aflatoxin $B(1)$, and p53 codon 249 mutation in hepatocellular carcinomas from Guangxi, People's Republic of China, and a meta-analysis of existing studies. Cancer Epidemiol Biomarkers Prev. 2001;10:617-25

38. Long J, Wang Y, Li M, Tong WM, Jia JD, Huang J. Correlation of TP53 mutations with HCV positivity in hepatocarcinogenesis: identification of a novel TP53 microindel in hepatocellular carcinoma with HCV infection. Oncol Rep. 2013;30:119-24.

39. Kuang SY, Lekawanvijit S, Maneekarn N, Thongsawat S, Brodovicz K, Nelson K, et al. Hepatitis B 1762T/1764A mutations, hepatitis C infection, and codon 249 p53 mutations in hepatocellular carcinomas from Thailand. Cancer Epidemiol Biomarkers Prev. 2005;14:380-4

40. Villar S, Ortiz-Cuaran S, Abedi-Ardekani B, Gouas D, da Costa AN, Plymoth A, et al. Aflatoxin-induced TP53 R249S mutation in hepatocellular carcinoma in Thailand: association with tumors developing in the absence of liver cirrhosis. PLoS One. 2012:7:e37707.

41. Shirabe K, Toshima T, Taketomi A, Taguchi K, Yoshizumi T, Uchiyama $H$, et al. Hepatic aflatoxin B1-DNA adducts and TP53 mutations in patients with hepatocellular carcinoma despite low exposure to aflatoxin B1 in Southern Japan. Liver Int. 2011;31:1366-72

42. Tanaka S, Toh Y, Adachi E, Matsumata T, Mori R, Sugimachi K. Tumor progression in hepatocellular carcinoma may be mediated by p53 mutation. Cancer Res. 1993;53:2884-7.

43. Oda T, Tsuda H, Scarpa A, Sakamoto M, Hirohashi S. p53 gene mutation spectrum in hepatocellular carcinoma. Cancer Res. 1992;52:6358-64

44. Hayashi H, Sugio K, Matsumata T, Adachi E, Urata K, Tanaka $S$, et al. The mutation of codon 249 in the p53 gene is not specific in Japanese hepatocellular carcinoma. Liver. 1993; 13:279-81.

45. Shi CY, Phang TW, Lin Y, Wee A, Li B, Lee HP, et al. Codon 249 mutation of the p53 gene is a rare event in hepatocellular carcinomas from ethnic Chinese in Singapore. Br J Cancer. 1995;72:146-9

46. Katiyar S, Dash BC, Thakur V, Guptan RC, Sarin SK, Das BC. p53 tumor suppressor gene mutations in hepatocellular carcinoma patients in India. Cancer. 2000;88:1565-73.

47. Debuire B, Paterlini P, Pontisso P, Basso G, May E. Analysis of the p53 gene in European hepatocellular carcinomas and hepatoblastomas. Oncogene. 1993;8:2303-6.

48. Challen C, Lunec J, Warren W, Collier J, Bassendine MF. Analysis of the p53 tumor-suppressor gene in hepatocellular carcinomas from Britain. Hepatology. 1992;16:1362-6.

49. Kubicka S, Trautwein C, Schrem H, Tillmann H, Manns M. Low incidence of p53 mutations in European hepatocellular carcinomas with heterogeneous mutation as a rare event. J Hepatol. 1995;23:412-9

50. Bourdon JC, D’Errico A, Paterlini P, Grigioni W, May E, Debuire B. P53 protein accumulation in European hepatocellular carcinoma is not always dependent on p53 gene mutation. Gastroenterology. 1995; 108:1176-82.

51. Ozdemir FT, Tiftikci A, Sancak S, Eren F, Tahan V, Akın H, et al. The prevalence of the mutation in codon 249 of the p53 gene in patients with hepatocellular carcinoma (HCC) in Turkey. ] Gastrointest Cancer. 2010;41:185-9.

52. Nogueira JA, Ono-Nita SK, Nita ME, de Souza MM, do Carmo EP, Mello ES, et al. 249 TP53 mutation has high prevalence and is 
correlated with larger and poorly differentiated HCC in Brazilian patients. BMC Cancer. 2009;9:204.

53. Goldblum JR, Bartos RE, Carr KA, Frank TS. Hepatitis B and alterations of the p53 tumor suppressor gene in hepatocellular carcinoma. Am J Surg Pathol. 1993;17:1244-51.

54. Jiao J, Niu W, Wang Y, Baggerly K, Ye Y, Wu X, et al. Prevalence of aflatoxin-associated TP53R249S mutation in hepatocellular carcinoma in Hispanics in South Texas. Cancer Prev Res (Phila). 2018;11:103-12.

55. De Benedetti VM, Welsh JA, Trivers GE, Harpster A, Parkinson AJ, Lanier AP, et al. p53 is not mutated in hepatocellular carcinomas from Alaska Natives. Cancer Epidemiol Biomarkers Prev. 1995;4:79-82.
56. Navas MC Suarez I, Carreño A Uribe $D$, Ríos WA CortésMancera F, et al. Hepatitis B and hepatitis C infection biomarkers and TP53 mutations in hepatocellular carcinomas from Colombia. Hepat Res Treat. 2011;2011:582945.

57. Montoya-Guzmán M, Duque-Jaramillo A, Gaviria-Calle M, Hoyos S, Restrepo JC, Navas MC. Mutación R249S TP53 en pacientes con cirrosis y carcinoma hepatocelular en un hospital de Medellín. Rev CES Med. 2019;33:100-10.

58. Sepúlveda-Villegas M, Román S, Rivera-Iñiguez I, Ojeda-Granados C, González-Aldaco K, Torres-Reyes LA, et al. High prevalence of nonalcoholic steatohepatitis and abnormal liver stiffness in a young and obese Mexican population. PLos One. 2019;14:e0208926. 